\title{
"Establishment and development of insurance supervision in Russia and Ukraine: retrospective review"
}

\begin{tabular}{|c|c|}
\hline AUTHORS & $\begin{array}{l}\text { Alexander Arkhipov } \\
\text { Viktor Trynchuk (D) https://orcid.org/0000-0001-7435-0159 } \\
\text { R https://publons.com/researcher/1367594/viktor-trynchuk/ }\end{array}$ \\
\hline ARTICLE INFO & $\begin{array}{l}\text { Alexander Arkhipov and Viktor Trynchuk (2017). Establishment and development } \\
\text { of insurance supervision in Russia and Ukraine: retrospective review. Insurance } \\
\text { Markets and Companies, 8(1), 48-58. doi:10.21511/ins.08(1).2017.05 }\end{array}$ \\
\hline DOI & http://dx.doi.org/10.21511/ins.08(1).2017.05 \\
\hline RELEASED ON & Friday, 01 December 2017 \\
\hline RECEIVED ON & Friday, 13 October 2017 \\
\hline ACCEPTED ON & Friday, 17 November 2017 \\
\hline LICENSE & $\begin{array}{l}(\mathrm{cc}) \text { EY-No } \\
\text { This work is licensed under a Creative Commons Attribution-NonCommercial } 4.0 \\
\text { International License }\end{array}$ \\
\hline JOURNAL & "Insurance Markets and Companies" \\
\hline ISSN ONLINE & $2522-9591$ \\
\hline PUBLISHER & LLC "Consulting Publishing Company "Business Perspectives" \\
\hline FOUNDER & LLC "Consulting Publishing Company "Business Perspectives" \\
\hline
\end{tabular}

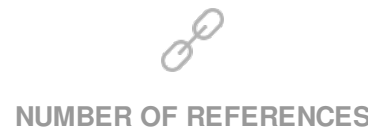

31
NUMBER OF FIGURES

0

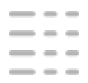

NUMBER OF TABLES

0

(C) The author(s) 2023. This publication is an open access article. 
Alexander Arkhipov (Russia), Viktor Trynchuk (Ukraine)

\title{
Establishment and development of insurance supervision in Russia and Ukraine: retrospective review
}

\begin{abstract}
The article considers main historical stages of the establishment and development of insurance supervision system in Russia and Ukraine. The objective necessity and the essence of state regulation of insurance business, its basic directions and methods providing a combination of interests of policyholders, the state and insurance companies are revealed. Attention is paid to the tendencies of content convergence and insurance supervision in many countries, as well as regulation of the insurance markets development. The changes and the implementation of the control and supervision function in the insurance field in recent history, the risks of tightening the regulatory regime are considered. The need to introduce effective regulatory and supervisory practices in insurance by the Russian megaregulator (Bank of Russia) and the National Financial Service of Ukraine is shown.
\end{abstract}

Keywords: history of financial institutions, insurance markets, state regulation, insurance supervision, insurance monopoly, megaregulator.

JEL Classification: N2, G220, G280.

Received on: $13^{\text {th }}$ of October, 2017.

Accepted on: $17^{\text {th }}$ of November, 2017.

\section{Introduction}

Insurance is of the greatest social importance among other financial services, as it affects the interests of the whole society, the economy and the state. In Russia and Ukraine, tens of millions of people are insured only on compulsory insurance of car owners' civil liability; also, the state uses insurance mechanisms to protect the public from emergencies and to finance the social sphere. Both comfort and welfare of millions of people and the state economic security depend on the insurance supervision efficiency and effectiveness. The analysis of historical documents proves the state's attention to insurance activity since its inception. Insurance supervision has been and remains an important tool of state social and financial policy.

Like other markets, the insurance market is affected by economic ups and downs. But unlike other markets, nowadays, the insurance market is characterized by an internal problems aggravation, expressed in a crisis of trust between the society and insurers. As experience confirms, it is impossible to resolve this crisis without regulating state participation.

The purpose of the article is to discuss the establishment and development of insurance

(c) Alexander Arkhipov, Viktor Trynchuk, 2017.

Alexander Arkhipov, Doctor of Economics, Professor, Department of Financial Markets, Plekhanov Russian University of Economics; Department of Risk Management and Insurance, MGIMO University, Russia.

Viktor Trynchuk, Ph.D. in Economics, Associate Professor, Department of Finance, Accounting and Analysis of Institute of Entrepreneurship and Advanced Technology Lviv Polytechnic National University; Head of Department of Insurance, Institute of Postgraduate Education and Business, Ukraine.

This is an Open Access article, distributed under the terms of the Creative Commons Attribution-NonCommercial 4.0 International license, which permits re-use, distribution, and reproduction, provided the materials aren't used for commercial purposes and the original work is properly cited supervision in Russia and Ukraine in historical retrospect due to a comparative analysis of the content and organization of insurance activities' state regulation to develop and justify measures to improve the regulatory system and enhance the insurance supervision effectiveness.

\section{Literature review}

In part, insurance business development in Ukraine and Russia in the late $19^{\text {th }}$ - early $21^{\text {st }}$ centuries can be traced on special aspects of creating and using the elements of sacred art in the insurance companies' corporate style (Trynchuk, 2017). In general, it should be noted that there are quite a lot of works on the insurance business establishment.

Most experts attribute the emergence of the insurance law in the Russian Empire (as a set of rules governing civil and legal relations with respect to the formation, preservation and use of insurance funds) by the end of the $18^{\text {th }}$ century. Catherine the Great, aiming for the development of Russian maritime trade, on November 23, 1781 approved the "Commercial Navigation Code" (hereinafter the Code of 1781); chapter X "On Insurance" contained all necessary provisions for maritime insurance, including the definition of insurance, insurance contract, the description of insured events, the insurer's responsibility to inform about the insurance object, apply for insurance in a timely manner, as well as his responsibility for the insurer's fraud, the insurer's liability for non-payment by the due date and the terms of release of his liability (Arkhipov, 2017).

The Code of 1781 formed the basis for the subsequent Russian legislation on merchant shipping and maritime insurance and it can be regarded as the first full-fledged Russian regulatory and legal act regulating this important and complex insurance industry. 
The next type of insurance, which received regulatory approval in Russia, was fire coverage of houses mortgaged in the bank. Catherine the Great Decree of June, 28, 1786 "On the establishment of the State Borrowed Bank (new) in favor of loyal our nobility and cities" and the Manifesto of December 23, 1786 "On the Establishment of Insurance Expedition" were an attempt to create a state bank that issued mortgages to noble landowners, but now the state has also controlled the insurance of the collateral. The Bank was obliged to produce fire insurance of stone, iron and tile roofed houses, which were pledged in the State Loan Bank, in a specially created Insurance Expedition, the first Russian insurance institution. Insurance of wooden houses and outbuildings, buildings with a reed or thatched roof were not allowed. In this case, the German experience was borrowed, when the pledged property insurance was made directly by the creditor bank itself (Maksakova, 2007).

The Manifesto of December 23, 1786 initiated the insurance in Russia on the state insurance monopoly terms. Banks were allowed to take on mortgage homes insured by foreign insurers subject to fine payment of $1.5 \%$ of the insured amount in favor of the Public Assistance Order, whose functions, in addition to purely social, included receiving deposits at interest, as well as issuing mortgage loan for a short period of time.

At the beginning of the 19th century, the state renounced the insurance monopoly and in 1800 Phoenix, the British insurer, due to the Insurance Expedition closure, was allowed to conduct insurance operations in Russia. Russian merchants made a number of attempts to open private insurance companies that led in 1827 and then in 1835 to the creation of the first and the second Russian fire insurance companies. In 1838, the Third fire insurance Company was established.

Due to fear of foreign capital in the insurance market, on April 14, 1818, a Decree was issued that prohibited the activities of foreign insurers on the Austrian Empire territory (Klapkiv \& Klapkiv, 2003). For many years, the Austrian Ministry of Internal Affairs did not give nod for new insurance companies to operate in Galicia. It was not until in 1860 that it was possible to set up "Florianka" - the society of mutual insurance against fire in Krakow. In the following years other insurance companies were established in Galicia: Vistula, Dnister, and Carpathia (Szczęśniak, 2003). The dominance of foreign capital of banks and insurers was the peculiarity of the financial market functioning during the period $1850-1939$ on the WestUkrainian lands.
A similar policy was pursued by the Russian Empire to protect the domestic insurance market. Thus, the first Russian insurers enjoyed the full support of the state, and to limit competition from foreign companies, each of them was granted an insurance monopoly in a number of provinces for a certain period.

The houses that were put into Public Assistance Order were also taken "in fear" on the special terms, in accordance with the highest approved opinion of the State Council of May 25, 1836 "On the rules for the buildings insurance in the second Russian fire insurance company for pledge in Public Assistance Orders". Since 1837, the first company began following these rules (Maksakova, 2007).

In 1846, Nicholas I approved the Charter of the "Salamander" insurance company, which received a 25-year monopoly on conducting insurance operations in the Bessarabian province, the Don Cossack Host region, Siberia and Transcaucasia. This was the last example of state support for the insurance company. With the privilege period expiry, the state monopoly on insurance has completely exhausted itself.

After the abolition of serfdom in 1861, under dynamic development of the economy, commercial (joint-stock) insurance companies and mutual associations (urban, country council and branch) started operating. These companies, along with foreign insurers, shaped the insurance market by the 1880 s.

The highest approved position of the Committee of Ministers "On the introduction of mutual insurance of property against fire in cities, settlements and towns of the empire" (October 10, 1861), signed by the Decree of Alexander II, initiated the mass organization of city mutual fire insurance companies (Insurance, 2014).

The private insurance sector development was facilitated by the credit and banking system reform, which, beginning in 1859, abolished the existing state credit institutions (the Loan Bank, the Conservation Treasuries and Orders of Public Assistance) and created public city and territorial banks; private banks for long-term property-secured loans and joint-stock commercial banks, mutual loan companies, rural loan and savings associations - for short-term loans. The statutes of newly created banks, as a rule, included the obligation of the borrower to insure the mortgaged estate. So, for example, the article of the Provision on city public banks stated that "anyone who wants to mortgage real estate must submit to the bank upon application ... an insurance "pole "if a loan is sought backed by the construction" (Complete, 1846). 
Due to the growing number of private insurance companies in the second half of the $19^{\text {th }}$ century, there was an urgent need for state control over their activities. Many newly established insurance companies for various reasons (because of competition in the market or imperfect organization of their activities) went bankrupt, which led to large financial losses both among shareholders and policyholders who lost all their savings (Railyan, 2005).

In 1887, Minister of the Interior, Count D. A. Tolstoy initiated the government oversight over the insurance companies' activities, just one year after the establishment of the first European body of insurance supervision - the Allied Insurance Bureau of Switzerland (Karpenko, 2010).

Initially, insurance supervision was established for foreign life insurance companies operating in Russia: the American New York and Equitable which often violated the terms of insurance, and the French Urbain. I. N. Durnovo continued the development of the Regulations and organization of insurance supervision. As a result, on June 06, 1894, Alexander III signed the "Regulations on Insurance Institutions and Societies Supervision", according to which the Insurance Department was established under the Economic Department of the Ministry of Internal Affairs. The committee consisted of two representatives from the Ministry of Internal Affairs and the Ministry of Finance. Head of the Economic Department was promoted to the position of The Chairman of the Insurance Committee. Paperwork was entrusted to the insurance department, whose staff consisted of the Department Manager and six auditors (Insurance, 2014).

It is characteristic that at the beginning of the $19^{\text {th }}$ century, in the Russian Empire, the regulatory functions for the supervision of exchange trade by the decree of Alexander I were assigned to the Ministry of Finance.

In 1898, led by the Insurance Committee under the Ministry of Internal Affairs, the law "On the procedure for placing and storing the funds of jointstock insurance companies and covering their obligations" was adopted, which regulated the investment operations of insurance companies. The funds that insurance companies could pay into cash, movable property and accounts of debtors should not exceed $40 \%$ of insurance capital. The same standard was set for investment in real estate. The highest amount of assets in terms of time deposits and balances on current accounts in private credit institutions and the choice of the latter were approved for each joint stock company separately by the Ministers of the Interior and Finance by mutual agreement. Therefore, free capital was placed in state loan bonds, in governmentguaranteed bonds of railways, in shares of commercial banks. Short-term loans for marketable collateral were also issued, for example, on the security of life insurance policies (Golitsyn, 2000).

According to the Provision of 1894, the Insurance Committee was entrusted with monitoring the observance by the insurance institutions and societies of the norms and rules of insurance, the safety and placement of capital, the analysis of financial statements, the appointment and conduct of audits and their results evaluation, the examination of complaints and petitions, the development of legal and organizational aspects of insurance business. The preservation of insurance funds was given a considerable attention in the Provision of 1894. Thus, according to paragraph 8 of the Provision, the insurance company auditing consists in checking the company's cash and the way of their placement, as well as the correctness of the society's deduction of premium reserves. If, at the same time, it turns out that the fixed assets and premium reserves are not covered by interestbearing securities, real estate and loans issued under the security of interest-bearing securities and life insurance policies, then the auditors are also included in the accounts of the debtors and in these cases, have the right to require presenting all the data on the status of the cash position and accounts of the insurer.

The Provision of 1894 provided for the insurers' duty to notify the Insurance Committee about the recruited agents.

With the development of supervisory practice, the Provision of 1894 was amended and supplemented. In 1906, norms were introduced to determine the reserves to be deducted from premiums received for life insurance and other types. It is noteworthy that Russian and foreign life insurance companies did not have the right to invest their own funds and reserves outside of Russia.

In 1898, after the Law "On the procedure for placing and storing the funds of joint-stock insurance companies and covering their obligations" was adopted on the initiative of the Insurance Committee, which regulated the investment operations of insurance companies, the Rules were specified on the procedure for placing and storing the funds of joint-stock insurance companies and coverage their obligations (as part of the Provision on Supervision), providing, inter alia, requirements for the composition and structure of assets to place insurance reserves and equity. 
Similar requirements, with changing names of assets and numerical values of standards, are applied by insurance supervision to the present time.

Noteworthy are the norms of the Provision on Supervision concerning the liquidation of insurance joint-stock companies, according to which, first of all, the insurer's debts are paid for unpaid insured events of the insured, as well as the amounts due on other debts. The amounts remaining for covering the obligations of the insurer are distributed among its shareholders.

Thus, the Provision on Supervision of 1894 (with subsequent amendments) was systemic in nature, provided for the control of virtually all spheres of insurer activity and served as a pattern for many subsequent normative documents of insurance supervision in Russia and Ukraine until the beginning of the $21^{\text {st }}$ century.

The Insurance Committee introduced requirements to the minimum amount of the authorized capital in the amount of 500 thousand silver rubles for each type of insurance (higher than current values, taking into account changes in the purchasing value of the ruble and hryvnia), limiting the size of the organizational expenses of insurance companies (such a requirement is not available today, unfortunately, which leads to the medium and small insurers depletion) and the cost of dividends to shareholders, determination of the reserve to be deducted from the received insurance premiums and providing insurance coverage to the insured (Insurance, 2014).

Financing of the Insurance Committee was effected by the Treasury (state budget), but in addition to reimbursement of expenses for insurers supervision, an annual special charge was established in favor of the Treasury. In 1894-1897, the collection was fixed at $0.25 \%$ from the received life insurance premiums and $0.1 \%$ from the received premiums for other types of insurance.

In 1904, the Insurance Committee was abolished and instead a Special Office for Insurance and Firefighting Measures of the Council for Local Economy Affairs of the Ministry of Internal Affairs was established. Staff of officials increased to 37 people after the reorganization. It is surprising that the traditions of voluntary annual reports publication in the mass media, laid down in the $19^{\text {th }}$ century by insurance societies, are now the responsibility of modern insurers both in Ukraine and Russia (Insurance, 2014).

It should be noted that along with the aforementioned normative acts and the Law of May
30, 1905 "On the insurance of incomes and capital through savings banks", which allowed state savings banks to engage in life insurance, the general civil laws of the Russian Empire included only two articles on the property insurance. According to Article 2199 of "Code of Civil Laws ", the contract of property insurance was defined as follows: "insurance is a contract, according to which a company or private person engaged in protection from accidents accepts a ship, goods, house or other movable and immovable assets for a fixed premium or fee, undertaking to satisfy damage or loss from supposed danger that can occur". In Article 2200 of the "Code of Civil Laws" it was determined that "insurance companies are set up on shares and are established on general rules of associations, or with special advantages approved by the government and based on their statutes".

Therefore, various norms of customary law, as well as foreign insurance legislation played an important role in insurance sector, especially in marine insurance, since the new version of the Commercial Charter adopted in the $19^{\text {th }}$ century did not meet the trade turnover needs. Insurance companies made policies, using German, English, French and Italian legislation, from the 1870s - the "Hamburg Maritime Insurance Regulations" of 1867 (Fogelson, 2012).

The lack of one whole regulatory legal act was a serious shortcoming in the legal regulation of insurance relations in Russia. The interests of the state, insurers, and insurance companies required to establish uniform insurance rules for all homogeneous institutions engaged in insurance activities. Measures to codify Russian insurance law began as early as 1879, when Alexander II established a commission to draft a civil code. As a result of the commission's work in 1899, book V was published, containing provisions on obligations (including insurance), but only in 1913, this bill was submitted to the State Duma for consideration and, by virtue of subsequent military and revolutionary events, was not adopted. In other European countries work on the codification of insurance law has also intensified. For example, in Switzerland the corresponding bill was finally developed in 1903, in Germany the draft law on the insurance contract was introduced in the Reichstag only in 1906. At the beginning of the $20^{\text {th }}$ century similar bills were developed in Austria, France and England (Raylian, 2005).

Along with commercial and reciprocal property insurance, in the late $19^{\text {th }}$ and early $20^{\text {th }}$ century, in Russia, following other large European countries, social insurance was developed, initially - pension insurance under the Charter on pensions and lump- 
sum benefits to civil servants of December, 06, 1827 , and later - indentured servants in the case of disability. The Law of June 06, 1903 "On remuneration of workers and employees injured from accidents, as well as members of their families in enterprises of the factory, mining and mining industry" introduced the entrepreneur's liability for occupational risk in the event of injury to workers or death due to accidents in production. In 1912, the Third State Duma passed the laws "On securing workers in case of illness", "On insurance of workers against accidents at work", "On approval of the Council for Workers "Insurance", and "On Approval of the Office for Employees' Insurance", but a detailed analysis of these laws is beyond the scope of this study.

\section{State insurance monopoly}

Naturally, the change of political power in the country in 1917 gave rise to cardinal changes not only in the insurance supervision system, but also in the insurance market as a whole. It is worth paying attention to the fact that at the first stage of the insurance business transformation, the commercial basis of insurance was retained. Decree of the Council of People's Commissars (Sovnarkom) of the RSFSR of March 03, 1918 "On the establishment of state control over all types of insurance, except for social insurance" established a special Insurance Council, the executive body of which was the Commissariat for Insurance (Moiseenko, 2014).

Along with the actual insurance policy direction in order to "bring insurance closer to the needs of the poorest population groups", the Decree of March 23, 1918 considered issues such as the development of scientific bases for charging insurance premiums and teaching the necessary instructions on this issue, which are absent in modern normative documents.

The next stage is due to adoption of the Council of People's Commissars Decree of the RSFSR dated November 28, 1918 "On the Organization of Insurance Business in the Russian Republic", where insurance in all its types and forms, such as fire insurance, transport, life insurance, accident insurance, hail damage, loss of cattle, crop failure, etc., is declared a state monopoly (Decree, 1918). Only mutual insurance of material assets of cooperative organizations "on special grounds" and life insurance at the state savings banks "on previous terms" were kept. All private insurers were liquidated, and country (people's soviet) and mutual city insurance organizations were declared the RSFSR property, and the monopoly state insurance management was entrusted to the Supreme Council of the National Economy, where the fire and insurance department was established (Zhuravin, 2005).

Pursuant to the instructions of the Decree of the Sovnarkom of the RSFSR dated November 28, 1918, the Decree of Sovnarkom of the RSFSR as of October 06, 1921 "On State Property Insurance" was adopted. It decided to organize state property insurance of private farms in all localities of the RSFSR, both rural and urban, from the natural disasters such as: fires, loss of cattle, hail damage of plant crops, as well as accidents on waterways and land transport. The decree opened the third stage of the Soviet insurance development, based on state monopoly. However, cooperative organizations retained the right for mutual insurance of their property against natural disasters and independently establish forms and types of insurance and tariffs subject to certain conditions. But in the 1930s, cooperative insurance was liquidated and its functions transferred to the State Insurance (Gomellia, 2011).

The Decree of October 07, 1921 was of an organizational nature, therefore the Decree of the Sovnarkom of the RSFSR dated July 06, 1922 "On State Insurance" was adopted, which determined that the state insurance is built based on commercial calculation and established its financial basis. This Decree actually transferred to the People's Commissariat of Finance the powers of insurance supervision, which was later fixed in the Provision on the People's Commissariat of Finance of the USSR, approved by Resolution of the Central Executive Committee of the USSR dated November 12, 1923.

The terms of contractual relations in insurance were codified in Chapter XI "Insurance" of the Civil Code of the RSFSR, approved by the Resolution of the All-Russian Central Executive Committee dated November 11, 1922 and the Civil Code of the Ukrainian SSR, approved by the Resolution of the Central Executive Committee dated December 16, 1922, which, in particular, contained the following definition of insurance: "by the insurance contract, one party (the policyholder) undertakes to pay the agreed contribution (insurance premium), and the other party (the insurer) undertakes to reimburse the insured or third party (the beneficiary) the losses incurred in the event provided for in the contract (insurance event) within the amount agreed upon by the contract (the insured amount), in case of personal insurance - to pay the insurance sum" (Tsivilny, 1922).

Many insurance standards, often verbatim, have entered into Chapter 48 of Part Two of the Civil Code of the Russian Federation dated June 26, 1996 
and Chapter 67 of Section III of the Civil Code of Ukraine dated June 16, 2003. But in the USSR, these norms were almost not applied due to consolidation of the state insurance monopoly.

The state monopoly on all types of insurance and exception to it, the list of operations (types) and the basic conditions of state insurance, the structure and distribution of powers, the source of funds and the reporting of state insurance bodies were finally formulated in the "Provision on State Insurance of the USSR", approved by the Resolution of the Central Executive Committee of the USSR, Council of People's Commissars of the USSR dated September 18, 1925, which can be regarded as the main normative document for the management and supervision of state and cooperative (before it was terminated in the 1930s) insurance (Provision, 1925).

These documents have ensured the sustainable development of the state insurance monopoly for almost 70 years. There were short-term attempts to revive social insurance during the New Economic Policy period, and in the early 1930s a centralized social security system was established.

The next stage in the history of state insurance is counted from the adoption of the Law "On Mandatory Salary Insurance" dated April 04, 1940, which specified the subject (buildings and cattle owned by citizens) and conditions (insured events, insurance amounts, tariffs, insurance payments) of compulsory insurance and provided universal housing protection against natural and other disasters. In practice, the State Insurance Committee of the USSR faced insurance premiums underpayment, which, according to Article 26 of the USSR Law of April 04, 1940, was converted to arrears, on which a penalty was charged at the rate of $0.1 \%$ of the insured amount for each overdue day.

Since December 1942, the system of personal insurance has fundamentally changed. Collective insurance, which became unprofitable, was canceled. Individual mixed insurance, death and disability insurance and accident insurance were introduced.

With the growth of operations and due to the expansion of insurance activity abroad in 1947, the Foreign Insurance Division of the USSR with the status of an independent legal entity (hereafter Ingosstrakh) was separated from the State Insurance of the USSR.

For the personal insurance development, the introduction in 1985 of the new Rules for Mixed Life Insurance was a landmark event. Citizens were given the right to conclude contracts for 5 years, not only for 10,15 and 20 years, as it was before. A significant role in the development of the insurance business was played by the Resolution of the Council of Ministers of the Ukrainian SSR dated November 26, 1958, No. 1645, "On the Approval of the Regulation on State Insurance Bodies in the Ukrainian SSR", which provides for the introduction of insurance protection of agricultural enterprises (Provision 1958), and especially the Resolution of the Council of Ministers USSR dated 30.08.1984 "On measures to further develop state insurance and improve the quality of insurance bodies", providing for the strengthening of the material and technical base of the system of the State Insurance in the USSR, change in profit distribution mechanism, and the reserves and funds formation (About measures, 1984; Gorevoy \& Suslikov, 2012).

In general, the state insurance system in the USSR was quite effective in regards to completeness of insurance coverage of life, health and property of the population and state interests, and in many respects not inferior to the insurance systems of developed countries - for example, the Soviet mandatory crop insurance system served as a pattern for many countries (Kolomin \& Arkhipov, 2001).

\section{The recent history of insurance supervision in Russia and Ukraine}

With the adoption of the USSR Law dated May 26, 1988 No. 8998-XI "On Cooperation in the USSR" in the Union, and after its disintegration in the Russian Federation and Ukraine, the formation of national insurance markets and independent insurance supervision bodies began. The historical analysis of the current period of insurance business development in the Russian Federation and Ukraine makes it possible to single out several stages with common features.

The first stage (in Russia in 1990-1992, in Ukraine - until 1996) is the private insurers independent development before the basic laws adoption: Law of the Russian Federation dated November 27, 1992 No. 4015-1 "On the Organization of Insurance in the Russian Federation", Cabinet of Ministers of Ukraine Decree "On Insurance" dated May 10, 1993 and the Law of Ukraine "On Insurance" as of March 07, 1996. Prior to 1993, in the Russian Federation and in Ukraine the national Ministries of Finance carried out insurers licensing. In order to ensure the state insurance policy implementation and in accordance with Article 30 of the RF Law dated November 27, 1992 No. 4015-1 The Russian Federal Service for Supervision of Insurance 
Activities (FSIS, Rosstrakhnadzor) was established by the Resolution of the Council of Ministers and Government of the Russian Federation dated April 19, 1993. In Ukraine, in accordance with the Cabinet of Ministers of Ukraine Decree dated September 17, 1993, the Committee on Insurance Supervision Affairs was established (Reverchuk, 2005), which existed until 2000 (Ukrstrakhnaglyad). It is characteristic that an independent body of insurance supervision in Ukraine was established before the adoption of the basic law “On Insurance” dated 07.03.1996.

The second stage (in Russia in 1993-2011, in Ukraine in 1996-2003) is the autonomous development of national insurance markets in accordance with the basic laws on insurance under the supervision of an independent state body. The universal features of this stage for the countries under consideration are the development of requirements for the insurers' financial stability, insurance intermediaries, authorized capital, reinsurance, the terms of the insurance contract, and the introduction of mandatory civil liability insurance for vehicle owners. A common feature of this phase was a temporary return of the insurance supervision functions to the Ministry of Finance (in the Russian Federation in the period 1996-2004, in Ukraine - in 2000-2002, in the department of financial institutions and markets). Since 2001, the requirements to the authorized capital of insurers have been raised and the activity of resident insurers with the participation of foreign capital up to $100 \%$ is permitted, according to the 1996 law, the norm was not over $49 \%$.

The third stage (in Russia in 2011-2013, in Ukraine from 2003 to the present) is the system development of the insurance market as part of the financial services market. A typical difference at this stage is the financial services dissociation: in Russia during this period, the insurance supervision functions were transferred to the Federal Service for Financial Markets (FSFM) by the Presidential Decree No. 270 dated March 04, 2011. The supervision of all financial services was shared between two government agencies: the Federal Financial Markets Service and the Bank of Russia. In Ukraine, according to the Law of 12.07.2001 No. 2664-III "On Financial Services and State Regulation of Financial Services Markets", the State Commission for Regulation of Financial Services Markets of Ukraine (Financial Services Commission) was established. After amending the law of 12.07.2001 No. 2664-III Financial Services Commission was transformed by the Decree of the President of Ukraine dated 23.11.2011 № 1070/2011 to the National Commission, which carried out state regulation in the financial services markets (National Financial Service). The Ukrainian securities market is regulated by the National Commission on Securities and the Stock Market (NCSSM), and banking sector - by the National Bank of Ukraine (NBU). The specific distinction of current Ukrainian insurance legislation, unlike the Russian Federation, is the allowance of the foreign insurer branches' activity.

The fourth stage (in the Russian Federation from 2013 to the present, in Ukraine - has not yet come) is the mega-regulation of all financial markets by the Bank of Russia, which obtained the FCSM's functions in accordance with Federal Law No. 251FZ dated July 24, 2013 "On Amendments to the certain legislative acts of the Russian Federation due to the delegating the Central Bank of the Russian Federation to regulate, control and supervise the financial markets" (Arkhipov, 2015).

The Russian insurance market positively responded to the creation of a mega-regulator based on the Bank of Russia, but representatives of insurers and experts noted that many areas of the Russian insurance market need additional legislative and supervisory regulation. In 2014-2016, Bank of Russia initiated significant changes to the Law of the Russian Federation dated November 27, 1992 No. 4015-1 regarding the terms for licensing the insurance business subjects, internal control of insurers, the minimum amount of authorized capital, and revised the conditions for the formation and placement of insurance reserves and own funds, and the requirements for the assets to obligations ratio. A common feature of this period was the crisis in the Russian and Ukrainian insurance markets. Among the reasons for this phenomenon experts mention distrust of the society to insurers, and in Ukraine - an additional loss of control over a part of the territory as well as state regulation and supervision ineffectiveness (Zaletov, 2014).

Kurylo, Kurylo, Zhovnirchyk, Kartashov, and Sokol (2017) studied in detail the functioning of the Ukrainian insurance market taking into account the latest trends in the world economy. The authors note an extremely small volume of premiums, inadequate coverage of the population and business organizations, trends, and determine conditions and development of the Ukrainian insurance market factors, as well as its prospects and Ukraine's role in the global insurance market.

Due to the crisis phenomena in the insurance market and the plans for European integration since 2014, Ukraine is actively discussing projects to improve insurance supervision, and in particular, in the first reading, a bill was passed to transfer part of the 
functions from the National Financial Service to the National Bank and the National Securities and Stock Market Commission. This project has opponents who believe that a simple transfer of regulatory functions does not solve the market problem and the NBU is not institutionally ready for this (Mega-regulator, 2017).

The adoption of the law on the task sharing of the National Commission that regulates financial services (the so-called "split" of the National Financial Service functions) is included in the memorandum of cooperation between Ukraine and the International Monetary Fund in 2017.

As a result of the reform, the following measures are scheduled.

Corrective measures provide for some recommendations to insurers based on inspections in order to eliminate shortcomings threatening stability. They will not be mandatory. But insurers who do not comply with these recommendations will fall into the zone of increased attention from supervision and will be classified as the most risky.

Fines, warnings and other sanctions must encourage insurers to prevent future violations. The suppression of violations will result in some restrictions imposed on the company activities. National Financial Service also offers to introduce the "fictitious activities" term. The presence of fictitiousness will mean the exclusion of the insurer from the register, up to its forced elimination (Pashko, 2016).

Obviously, the aim of creating a megaregulator both in Russia and Ukraine is not simply to unite the supervisory bodies in one institution, but also to ensure the reliability of the financial institutions functioning and to protect the interests of financial service consumers.

In the developed countries of Europe and Asia, in the USA, which have highly developed insurance markets, the stage of financial regulation consolidation is coming to end, which began in the 1980s and is marked by the creation of new models of regulators - megaregulators based on the suprasectoral principle, e.g. spreading their powers to several sectors of the financial market or even the entire national financial market. In addition to authorities expanding, the functionality of financial regulator activities also changes. The bodies of insurance regulation and supervision have new tasks at the global, regional and national levels, primarily on the systemic management of the financial service risks. The transition to mega-regulation is the main current trend in reforming financial regulation and, in the historical context, is a natural result of the sectoral regulation model evolution under the financial sector globalization and conglomeration. As variants of mega-regulation models, an "integrated" approach is used in which the functions of regulating financial markets are combined in a single body, for example, the Bank of Russia in the Russian Federation and the "twinpeaks" model, which provides for creating two institutions whose powers are divided based on a functional principle: macrostability and protection of the financial service consumers' rights, as, for example, in Australia and the Netherlands (Buklemishev, Danilov, \& Kokorev, 2015).

Most countries use a sectoral model; 33 countries have a single independent regulator that integrates regulatory functions with constitutive competences, supervision, and control; in 13 states central banks are engaged in megaregulating; in 4 countries a system of two peaks (twinpeaks) has been implemented (Danilov, 2012; Khominich \& Trinchuk, 2013).

Supervisory institution systems in many countries are undergoing significant changes. In a number of countries, for example, in France, there has been a merger of independent insurance supervision bodies with banking supervisory structures. In the UK, insurance regulation became a function of the Central Bank; it was divided into prudential regulation and regulation of market behavior between two new structures - the Prudential Regulation Authority (PRA) and the Financial Conduct Authority (FCA).

The most significant institutional changes took place in the United States, where the Federal Insurance Office (FIO) was established which monitored the insurance sector and represented the US position as to prudential aspects of insurance regulation at the international level. FIO is now working to modernize the requirements for the insurers' solvency, including within the framework of consolidated supervision. The Financial Stability Oversight Council (FSOC) was established, which also identified national systemically important insurers. The role of the Federal Reserve System (FRS) has increased as a consolidated regulator of a number of large insurance holdings (groups of companies), which account for almost a third of life insurance premiums collected in the United States and an increasing volume of premiums on general insurance (Arkhipov, 2017).

In order to improve supervisory methods and models, insurance supervisors attract their experts to making important decisions by insurers and using forecast analysis tools to monitor solvency in the future. The Bank of Russia applied this practice, 
introducing its supervisors in the top 20 insurers. Depending on the size of the premium collected, all insurers are divided into three groups. The first is the 20 largest systemically important insurers. These institutions will be under the strictest supervision. The second group is the following (in terms of premium volume) 80 insurers from the top 100. The third group contains other insurance organizations. Supervision of each of the second group companies will be carried out by the central office, and supervision of the third group will be carried out by representatives of three territorial institutions of the Bank of Russia (Moscow - for insurers of the Central Federal District, St. Petersburg - for insurers of districts in the European part of Russia, and Novosibirsk - for insurers, working beyond the Urals.

The activity of the supervisory authority in modern conditions should combine standard (current) measures, as well as preventive (proactive) actions aimed at early intervention in the work of the insurance company to prevent risks (Khominich, Parfenova, \& Savvina, 2015).

In this regard, in 2016, the Bank of Russia established the procedure for monitoring the insurer activities, approved by the Decree dated January 18, 2016. Monitoring is carried out at least once a quarter by evaluating the following indicators: 1) own funds (capital) and borrowed funds (except for mutual insurance companies); 2) profitability (combined indicator of unprofitability, profitability of equity, investments and profitability of the insurer as a whole); 3) quality and liquidity of assets; 4) quality of underwriting; 5) reinsurance operations; 6) the dynamics of the main financial indicators of the insurer (equity, assets and insurance premium by deducting net of reinsurance); 7) the ratio of own funds (capital) and accepted obligations (except for mutual insurance companies).

Among the numerical coefficients for assessing these indicators, we can single out a simple and original indicator of the insurance portfolio (to assess the quality of underwriting) diversification, calculated as the percentage of the sum of the squares of insurance premium by types of insurance to the square of the total insurance premium (excluding life insurers). At the same time, the risk assessment in the Monitoring Procedure is carried out exclusively according to the credit rating of the insurer's assets associated with banks, reinsurers, issuers or issuance of securities established by the Board of Directors of the Bank of Russia, without taking into account the insurer's own risks. However, in general, this approach is consistent with international practice, particularly the practice of insurance control bodies and audit services in some US states for the financial analysis of insurance operations. In total, up to 11 indicators, among which the premium to net profit ratio, premium dynamics, the ratio of net reinsurance profit to total net profit, a two-year general operating ratio, etc., are used. If the value of the three indicators goes beyond acceptable limits, then the insurer must be taken under a special control of state insurance supervision.

\section{Conclusion}

A comparative analysis of the insurance supervision history in Russia and Ukraine shows that before 1991 the Russian Federation and Ukraine had a general history of shaping the insurance institute and insurance supervision, and now have many common features resulting from this further independent development of national insurance markets and methods of its state regulation.

In the $19^{\text {th }}$ century, the foundations of state regulation of insurance activity were laid first through the state insurance monopoly, and later through a special state body of insurance supervision - the Insurance Committee in the Russian Empire. Control over insurance organizations' financial sustainability was the main area of the Committee's activity, and an attempt was made (not completed) to codify insurance legislation. The Ministry of Internal Affairs was the state body of insurance supervision in the Austrian empire.

The similarity of the main stages of the independent national development influenced the formation of insurance supervision bodies and the regulatory documents that provide them, including the chapters in the Civil Codes and the basic laws on insurance (insurance business), with the subsequent transition to the integration of financial supervisory authorities.

Later, during the Soviet period, insurance supervision returned to the form of state insurance monopoly. At the same time, the codification of insurance law was completed, which did not receive practical application due to the state monopoly on insurance, but served as a basis for preparing chapters on insurance for the current Civil Code of the Russian Federation and Ukraine.

The main factors that make it necessary to implement insurance supervision are: the important role of insurance as an institution of the state financial system, and protection of the policyholders' interests.

Both in Russia and in Ukraine, the insurance market is currently in crisis and is looking for points of 
further development. As time has shown, it is impossible to resolve crisis without regulating state participation. In order to solve this complex problem, it became necessary to conduct a comprehensive historical study of the development of insurance supervision forms and methods in Russia and Ukraine, taking into account the foreign countries' experience.

The Russian Federation has moved further in this direction and has already moved to the megaregulation of all financial markets based on the Bank of Russia. Significant similarity is observed in the packages of the main regulatory legal documents - in addition to the aforementioned laws, these are provisions on the insurance reserves formation and requirements for their placement, the requirements for the correlation of assumed obligations and assets, the rules for internal control of non-credit financial organizations in order to counteract proceeds of crime legalization (laundering) and terrorism financing. The revealed similarity suggests that even in the future, despite the known political differences, the insurance supervision development and, probably, the insurance market development will have similar features in the countries under consideration.

\section{References}

1. Arkhipov, A. Р. (2015). О роли Банка России в развитии страховой деятельности [O roli Banka Rossii v razvitii strakhovoy deyatelnosti]. Proceedings of the XVI International scientific and practical conference (June 25, 2015, Yaroslavl): Strategy of development of insurance activity: first results, problems, perspectives (pp. 7-16). YarGU, ROSGOSSTRAKH.

2. Arkhipov, A. P. (2017). Страховой надзор в России. Становление, использование зарубежного опыта, перспективы развития [Strakhovoy nadzor v Rossii. Stanovlenie, ispolzovanie zarubezhnogo opyta, perspektivy razvitiya] (184 p.). Moscow: RUSAINS.

3. Buklemishev, O. V., Danilov, Yu. A., Kokorev, R. А. (2015). Мегарегулятор как результат эволюции финансового регулирования [Megaregulyator kak rezultat evolyutsii finansovogo regulirovaniya]. Vestnik Moskovskogo Universiteta, Ser. 6, Ekonomika, 4, 52-74.

4. Danilov, Yu. (2012). Остановить монстра! [Ostanovit monstra!]. Retrieved from http://www.insurinfo.ru/press/82474/

5. Fogelson, Yu. B. (2012). Страховое право: теоретические основы и практика применения [Strakhovoе pravo: teoreticheskie osnovy i praktika primeneniya]. Moscow: Norma, Infra-M.

6. Golitsyn, G. (2000). Российские страховые компании до революции [Rossiyskiye strakhovye kompanii do revolyutsii]. Investitsii plus, February 21, 2000. Retrieved from http://www.insur-info.ru/history/press/45727/

7. Gomellia, V. B. (2011). Страхование [Strakhovanie] (4 ${ }^{\text {th }}$ ed.). Moskovskaya finansovo-promyshlennaya akademiya.

8. Gorevoy, Ye. D., Suslikov, V. N. (2012). История развития российского страхового законодательства [Istoriya razvitiya rossiyskogo strakhovogo zakonodatelstva]. Grazhdanskoe pravo, 2.

9. Karpenko, V. M. (2010). Банкротство страховых организаџий в России и EC [Bankrotstvo strakhovykh organizatsiy v Rossii i ES]. Informatsyonnyi bank "Postateinye kommentarii i knigi".

10. Khominich, I. P., Parfenova, L. B., Savvina, O. V. (2015). Страховой надзор в контексте глобальных реформ финансового регулирования [Strakhovoy nadzor v kontekste globalnykh reform finansovogo regulirovaniya]. Proceedings of the XVI International scientific and practical conference (June 2-5, 2015, Yaroslavl): Strategy of development of insurance activity: first results, problems, perspectives (pp. 7-16). YarGU, ROSGOSSTRAKH.

11. Khominich, I., Trinchuk, V. (2013). Мегарегулятор финансовых институтов в России: влияние на страховой рынок [Megaregulyator finansovykh institutov v Rossii: vliyaniye na strakhovoy rynok]. Proceedings of the $V$ International scientific and practical conference (February 19, 2013): Modern economy: concept and models of innovative development (pp. 326-330). Moscow: FGBOU VPO "REU im. G. V. Plekhanova".

12. Klapkiv, M., Klapkiv, Yu. (2003). Витоки національного страхового ринку Украӥни [Vytoky natsionalnogo strakhovogo rynku Ukrayiny] (275 p.), Ternopil, Kart-blansh.

13. Kolomin, Ye. V., Arkhipov, A. P. (2001). K вопросу управления рисками в агропромышленном комплексе [K voprosy upravleniya riskami v agropromyshlennom komplekse]. Problemy prognozirovaniya, 5, $150-152$. Retrieved from https://ecfor.ru/publication/k-voprosu-upravleniya-riskami-v-agropromyshlennom-komplekse/

14. Kurylo, V., Kurylo, L., Zhovnirchyk, Ya., Kartashov, Ye., Sokol, S. (2017). The development of the insurance market of Ukraine amid the global trends in insurance. Investment Management and Financial Innovations, 14(11), 211-216. http://dx.doi.org/10.21511/imfi.14(1-1).2017.07

15. Maksakova, Ye. А. (2007). Страхование ипотечных кредитов в России (фрагменты истории) [Strakhovanie ipotechnykh kreditov v Rossii (fragmenty istorii)]. Bankovskoe pravo, 5.

16. Moiseenko, M. В. (n.d.). Страховому надзору в России - 120 лет [Strakhovomu nadzoru v Rossii - 120 let]. Retrieved from http://www.insur-info.ru/interviews/943/?utm_source=twitterfeed\&utm_medium=twitter

17. Pashko, I. (n.d.). Начать с чистого листа. Страховой сектор Украины получит новую и эффективную модель надзора [Nachat s chistogo lista. Strakhovoy sektor Ukrainy poluchit novuyu i effektivnuyu model nadzora]. Retrieved from http://forinsurer.com/public/16/09/20/4757 
18. Raylian, A. I. (2005). Обзор нормативно-правового регулирования страхового дела в Российской империи [Obzor normativno-pravovogo regulirovaniya strakhovogo dela v Rossiyskoy imperii]. Advokatskaya praktika. Retrieved from http://www.insur-info.ru/press/94078/

19. Reverchuk, S. K. (Ed.), Syva, T. V., Kubiv, S. I., Vovchak, O. D. (2005). Iсторія страхування [Istoriya strakhuvannia] (213 p.), Kyiv, Znannia.

20. Szczęśniak, M. (2003). Zarys dziejów ubezpieczeń na ziemiach polskich (378 p.). Warszawa: Wyższej Szkoły Ubezpieczeń i Bankowości (in Polish).

21. Trynchuk, V. (2017). Management of visual communications in insurance companies (on the example of using icons in logos). Problems and Perspectives in Management, 15(2-2), 319-331. http://dx.doi.org/10.21511/ppm.15(2-2).2017.02

22. Zaletov, A. (n.d.). Страховая политика и стратегия ее формирования в условиях «идеального шторма» [Strakhovaya politika i strategiya yeyo formirovaniya $\mathrm{v}$ usloviyakh idealnogo shtorma]. Retrieved from http://forinsurer.com/public/15/04/14/4717

23. Zhuravin, S. G. (2005). Краткий курс истории страхования [Kratkiy kurs istorii strakhovaniya] (112 p.). Ankil.

24. Декрет Совета Народных Комиссаров. Об организации Страхового дела в Российской Республике [Dekret Sovieta Narodnykh Komissarov. Ob organizatsii Strakhovogo dela v Rossiyskoy Respublike]. Retrieved from http://istmat.info/node/31902

25. Мегарегулятор та «спліт»: чи потрібні вони зараз на небанківському ринку України? [Megareguliator ta "split": chy potribni vony zaraz na nebankivskomu rynku Ukrainy?] Retrieved from https://www.ukrinform.ua/rubric-presshall/2344955-megaregulator-ta-split-ci-potribni-voni-zaraz-nebankivskomurinku-ukraini.html

26. О мерах по дальнейшему развитию государственного страхования и повышению качества работы страховых органов [O merakh ро dalneyshemu razvitiyu gosudarstvennogo strakhovaniya i povysheniyu kachestva raboty strakhovykh organov]. Postanovlenie Sovmina SSSR ot 30.08.1984 No. 932. Retrieved from http://lawru.info/dok/1984/08/30/n1183045.htm

27. Полное собрание законов Российской империи [Polnoye sobraniye zakonov Rossiyskoy imperii] (2 ${ }^{\text {nd }}$ ed.), vol. XXII. Saint Petersburg: Tipografiya II otdeleniya sobstvennoy E.I.V. kantselyarii.

28. Положение о государственном страховании Союза Советских Социалистических Республик [Рolozheniye o gosudarstvennom strakhovanii Soyuza Sovetskikh Sothialisticheskikh Respublik] (UTV. TSYK SSSR, SNK SSSR 18.09.1925). Retrieved from http://pravo.levonevsky.org/baza/soviet/sssr6830.htm

29. Про затвердження Положення про органи державного страхування в Українській PCP [Pro zatverdzennia Polozhennia pro organy derzhavnogo strakhuvannia v Ukrayinskiy RSR] vid 26 lystopada 1958 No. 1645. Retrieved from http://search.ligazakon.ua/1_doc2.nsf/link1/KP581645.html

30. Страховые общества в России (2014). [Strakhovyye obshchestva v Rossii] (240 p.). Moscow: Chelovek.

31. Цивільний кодекс УРСР, затверджений Постановою ЦВК УРСР від 16 грудня 1922 p. [Tsyvilnyi kodeks URSR, zatverdzhenyi Postanovoiu TsVK URSR]. Retrieved from http://deminov.dp.ua/grazhdanskoe-pravo-iprocess/ck-codecs-ussr-1922 